Gut, 1980, 21, 683-688

\title{
Effects of salicylate on intestinal absorption: in vitro and in vivo studies with enterotoxigenic micro-organisms
}

\author{
VALERIE BURKE AND M GRACEY* \\ From the Gastroenterological Research Unit, Princess Margaret Children's Medical Research Foundation, \\ Perth, Western Australia
}

SUMMARY This study was done to determine whether salicylate could affect alterations in intestinal absorption induced by preparations of enterotoxigenic micro-organisms. It was found in rats that salicylate increased intestinal monosaccharide uptake in vitro and reversed the inhibitory effects induced by cell-free preparations of Staphylococcus sp., Candida $\mathrm{sp}$. and Klebsiella sp. In vivo, salicylates increased net water absorption in rat jejunum exposed to cell-free preparations of various micro-organisms. Increase in net fluid flux occurred after subcutaneous injection only with bacteria which stimulate adenylate cyclase activity. These observations suggest that the absorptive and anti-secretory effects of aspirin are cyclic nucleotide dependent. The potential clinical role of salicylates as anti-secretory agents in diarrhoeal diseases, particularly in children, requires further investigation.

Diarrhoea remains a major problem in malnourished children in developing countries. Bacterial overgrowth in the small intestine is common in such children $^{1}$ and, although many of the organisms found in large numbers in their upper intestines are not generally considered to be enteric pathogens, they can inhibit intestinal transport of sugar ${ }^{2}$ and cause intestinal secretion of fluid ${ }^{3}$. It may be that diarrhoea in malnourished children is related to contamination of the upper intestine with such mixed bacterial populations as well as to recognised enteric pathogens such as $V$. cholerae, E. coli, Shigella sp., and Salmonella sp.

Aspirin has been shown to inhibit intestinal secretion caused by cholera toxin, ${ }^{45}$ while bismuth subsalicylate inhibits secretory effects of crude $E$. coli enterotoxin and cholera toxin. ${ }^{6}$ Other anti-inflammatory agents such as indomethacin have also been found to inhibit secretion caused by cholera toxin, Salmonella typhimurium, and Shigella flexneri $^{7}$ as well as E. coli heat stable toxin (ST) ${ }^{8}$ Meanwhile, Farris et al. ${ }^{9}$ found that aspirin enhanced intestinal electrolyte transport in normal

*Address for correspondence and reprints: Dr Michael Gracey, Princess Margaret Children's Medical Research Foundation, GPO Box D. 184, Perth, Western Australia.

Received for publication 26 February 1980 ileum as well as in tissues exposed to cholera toxin. This finding suggests the possibility that aspirin may increase intestinal absorption even when diarrhoea is not caused by bacterial toxin. However, Nalin ${ }^{10}$ found that aspirin, given after the onset of intestinal secretion in dogs induced by cholera toxin, failed to prevent further secretion and for this reason considered a clinical trial of salicylates in cholera to be unjustified. Yet, indomethacin given after challenge with $E$. coli heat stable toxin (ST) effectively inhibits toxicity. ${ }^{8}$ These findings and claims indicate a need to investigate the potential antisecretory effects of such substances, particularly if they might have a useful, practical, therapeutic role in the control of fluid loss in childhood dairrhoeas.

We have therefore investigated the effect of aspirin on intestinal transport of sugar and water in normal rat jejunum in vitro and in vivo with and without exposure to a range of bacteria isolated from the upper small intestinal secretions of malnourished Indonesian children with diarrhoea. The organisms chosen were those we have previously found to affect intestinal transport processes; ${ }^{23}$ $E$. coli known to produce heat labile (LT) or ST toxins or both were also included in the study. In particular, we have examined the effect of aspirin given after intestinal water secretion has been 
induced by cell-free preparations of these microorganisms.

\section{Methods}

BACTERIAL STRAINS

Individual strains of Staphylococcus pyogenes, Staphylococcus epidermidis, Klebsiella pneumoniae, E. coli 055 , Shigella sonnei, Salmonella typhimurium, and Candida tropicalis isolated from the upper intestinal aspirates of malnourished Indonesian children, and shown previously to interfere with intestinal transport of sugar, fluid, or electrolytes, ${ }^{2} 3$ were used in these studies. In addition porcine strains of $E$. coli 431 (serotype 0101 : K30, OO:NM) producing ST only and 263 serotype 08: K87, 88ab:H19) producing LT only, and the human strain H10407 (serotype 078: K80:H11) and B7A producing both LT and ST were tested.

\section{PREPARATION OF CULTURE FILTRATES} Micro-organisms stored at $-70^{\circ} \mathrm{C}$ were grown aerobically in $100 \mathrm{ml}$ volumes of a casamino acidyeast extract medium ${ }^{11}$ in $250 \mathrm{ml}$ Erlenmeyer flasks in an environmental incubator shaker (New Brunswick Scientific, Edison, NJ, USA) at $300 \mathrm{rpm}$ and $37^{\circ} \mathrm{C}$ for 24 hours. Cultures produced bacterial cell populations of approximately $10^{8}$ per $\mathrm{ml}$ and were checked for microbiological purity and cell-free preparations made by centrifuging at $3000 \mathrm{rpm}$ for 30 minutes followed by filtration through a Millipore type HA filter (Millipore Corp. Bedford, Mass., USA). This solution was dialysed overnight against phosphate-buffered saline. For all control experiments uninoculated medium was processed identically. Osmolality of the dialysate was $300 \pm 10$ mosM.

ABSORPTION EXPERIMENTS

Adult male rats (Wistar, inbred albino) weighing 200-250 g were used in all experiments.

\section{In vitro STUDIES OF INTESTINAL} SUGAR UPTAKE

Animals were killed with anaesthetic ether after an overnight fast. The small intestine was removed, washed gently with physiological saline, and then everted. Peyer's patches were discarded and the remainder of the jejunum cut transversely into segments $1-5 \mathrm{~cm}$ long which were randomised in Krebs-Henseleit (KH) buffer ${ }^{12}$ at $\mathrm{pH} 7 \cdot 4$. Specimens were gently blotted and then mounted in plexiglass chambers. ${ }^{13}$ After preincubation for two minutes in KH buffer, the mounted specimens were transferred to beakers containing $30 \mathrm{ml}$ of incubation medium with four samples in each beaker. The medium contained $3 \mathrm{mM}$ arbutin (p-hydroxyphenyl- $\beta$ glucoside, Sigma, Chemical Co. London, UK) in KH buffer at $\mathrm{pH} 7 \cdot 4$, gassed with $\mathrm{O}_{2}: \mathrm{CO}_{2}(95: 5 \mathrm{v} / \mathrm{v})$. Tissues were incubated in a Dubnoff type shaker at $37 \pm 1^{\circ} \mathrm{C}$ in an atmosphere of $\mathrm{O}_{2}: \mathrm{CO}_{2}(95: 5 \mathrm{v} / \mathrm{v})$ for 10 to 50 minutes. After incubation, chambers were rinsed in buffer, the exposed tissue removed with a metal punch, then gently blotted and weighed. Samples were then homogenised and deproteinised. ${ }^{14}$

In the first series of experiments, acetyl salicylic acid was added to the incubation medium in a concentration of $1,5,10,15$, or $20 \mathrm{mM}$. The $\mathrm{pH}$ was adjusted to 7.4 with $\mathrm{NaOH}$ which added approximately $1.5 \mathrm{mmol}(3 \mathrm{meq} / \mathrm{l})$ of $\mathrm{Na}$ to the $10 \mathrm{mM}$ solutions. Arbutin uptake was also measured in the presence of $20 \mathrm{mM}$ salicylic acid.

In a second group of studies jejunal segments were incubated with $3 \mathrm{mM}$ arbutin in cell-free preparations of Klebsiella pneumoniae, Staphylococcus pyogenes, Candida albicans, or E. coli 263 prepared as described above. Results were compared with control values for arbutin uptake in uninoculated medium processed in the same ways with values for arbutin uptake with $10 \mathrm{mM}$ salicylic acid added to the cell-free bacterial preparations.

Jejunal arbutin uptake was also measured one hour after rats had been fed $20 \mathrm{mg} / \mathrm{kg}$ or $40 \mathrm{mg} / \mathrm{kg}$ aspirin or salicylic acid in $1 \mathrm{ml}$ water by stomach tube. Arbutin was determined as free phenol ${ }^{15}$ and 2-deoxy-glucose as described by Waravdekar and Saslaw. ${ }^{16}$ Results are expressed as $\mu \mathrm{mol}$ arbutin per mg of tissue after correction for 2-deoxy-glucose space.

In vivo STUDIES OF INTESTINAL

FLUID TRANSPORT

Perfusion fluid

Cell-free bacterial preparations were used, as described above, with uninoculated medium in control experiments. Phenol red, $5 \mu \mathrm{g}$ per $\mathrm{ml}$ (British Drug Houses, London, UK), was added to the perfusate as a non-absorbable marker for measuring water transport. Recovery of phenol red was $99 \%(\mathrm{SE} \pm 1 \cdot 58) .10 \mathrm{mM}$ salicylic acid was added to the perfusion fluid in some experiments.

\section{ABSORPTION EXPERIMENTS}

Rats were anaesthetised by the intraperitoneal injection of urethane (ethyl carbamate), $1 \mathrm{~g}$ per $\mathrm{kg}$ body weight, and body temperature maintained by a thermostatically controlled heated pad. Two cannulae were introduced through incisions in the gut wall, one at each end of an intact segment of jejunum approximately $20 \mathrm{~cm}$ in length, and tied in position with black silk. The gut segment was washed with $3 \mathrm{ml}$ of the perfusion solution described 
above, and then drained by gently syringing air through it. The segment was replaced in the abdominal cavity and perfused with the test solution at $10 \mathrm{ml}$ per hour. After equilibration for 30 minutes, perfusate was collected in three 30 minute samples for 90 minutes. At the end of the perfusion, the test segment was drained and its length measured under the tension of a standard weight.

Uninoculated medium and cell-free preparations of Klebsiella pneumoniae, E. coli 055, 263, 431, H10407 and B7A, Shigella sonnei, Staphylococcus epidermidis, Staphylococcus pyogenes, and Candida tropicalis were perfused with and without the addition of $10 \mathrm{mM}$ acetyl salicylic acid.

To determine the effect of aspirin given after changes in fluid transport had appeared, animals were perfused with cell-free bacterial preparations as described above. After allowing 30 minutes equilibration, perfusate was collected for 30 minutes. Rats were then given $50 \mathrm{mg} / \mathrm{kg}$ acetyl salicylic acid subcutaneously and perfusate collected in two 30 minute samples for a further hour.

Phenol red was determined spectrophotometrically at $560 \mathrm{~nm}$ using $0.5 \mathrm{ml}$ volumes of centrifuged samples made alkaline with $1 \mathrm{ml} 1 \mathrm{~N} \mathrm{NaOH}$.

\section{EXPRESSION OF RESULTS}

Net water flux is expressed in $\mu \mathrm{ml}$ of water transported per $\mathrm{cm}$ of intestine per hour; + indicates net absorption and - indicates net secretion.

\section{STATISTICAL METHODS}

Differences in arbutin uptake were assessed using multivariate analysis of variance in comparing curves for arbutin uptake as previously described.17 Net water flux was compared using analysis of variance. $\mathbf{P}<0.05$ was considered to be significant.

\section{Results}

\section{In vitro ARBUTIN UPTAKE}

In absence of bacterial preparations

Figure 1 shows that arbutin uptake increases with increasing concentrations of acetyl salicylic acid in the incubation medium. The difference was not statistically significant using $1 \mathrm{mM}$ acetyl salicylic acid but there was a significant difference with 5 , 10,15 , and $20 \mathrm{mM}$ acetyl salicylic acid or $20 \mathrm{mM}$ salicylic acid when compared with control values. After incubation for 10, 20, 30, 40, and 50 minutes the mean and SEM values for tissue arbutin\} at increasing concentrations of acetyl salicylic acid (ASA) were (a) controls: $3 \cdot 1(0 \cdot 3), 3 \cdot 6(0 \cdot 4), 3 \cdot 9(0 \cdot 3)$, 4.1 (0.3), 4.1 (0.6); (b) 5 mM ASA: 3.1 (0.6), 4.0 (0.6), $4.3(0.7), 5.0(0.6), 5 \cdot 3(0.6)$; (c) $10 \mathrm{mM} A S A$ : $3.8(0.4), 4.6(0.4), 5.2(0.4), 5.4(0.5), 5.5(0.3)$; (d) 15 mM ASA: $3 \cdot 8(0 \cdot 2), 4 \cdot 7(0 \cdot 3), 5 \cdot 1(0 \cdot 4), 6 \cdot 0(0 \cdot 6)$,

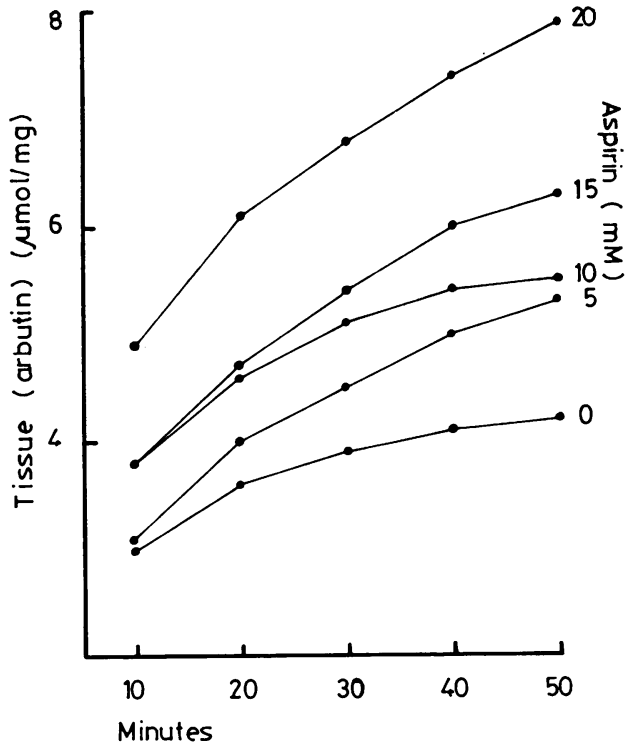

Fig. 1 Intestinal uptake of arbutin in vitro in the presence of increasing concentrations of aspirin in the incubation medium.

6.3 (0.5); and (e) $20 \mathrm{mM}$ ASA: $4.9(0.7), 6 \cdot 1(0 \cdot 7)$, $6.3(0.7), 7.4(0.4)$, and $7.9(0.6)$. For $20 \mathrm{mM}$ salicylic acid the \{arbutin mean and SEM values were at 10 minutes, $3.2(0.5)$; at 20 minutes, $4.0(0.5)$; at 30 minutes, $4.6(0.5)$; at 40 minutes, $5.1(0.6)$, and at 50 minutes, $5.5(0.7)$. In every instance $n=8$.

Similarly, feeding acetyl salicylic acid in a dose

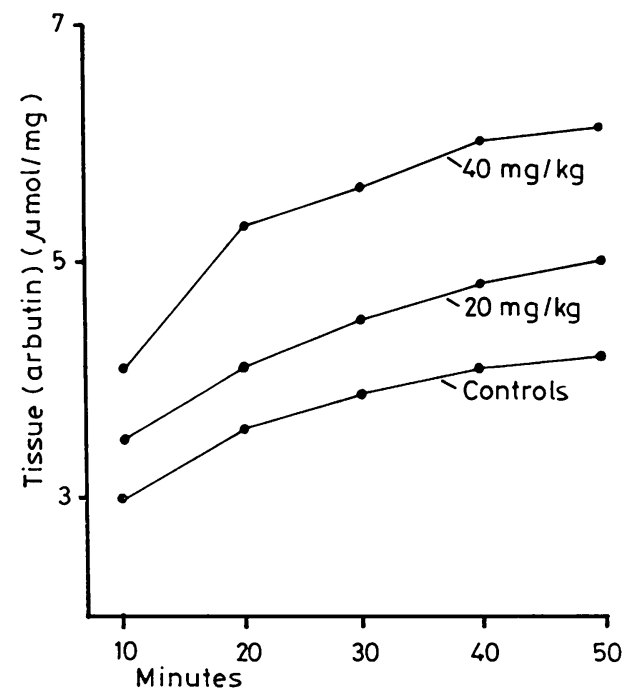

Fig. 2 Effect of prior feeding of acetyl salicylic acid on intestinal arbutin uptake. 
of $20 \mathrm{mg} / \mathrm{kg}$ or $40 \mathrm{mg} / \mathrm{kg}$ one hour before the experiment significantly increased arbutin uptake (Fig. 2). With $20 \mathrm{mg} / \mathrm{kg}$ of ASA the arbutin $\}$ mean and SEM values at $10,20,30,40$, and 50 minutes were $3.5(0.3), 4 \cdot 1(0.5), 4 \cdot 4(0 \cdot 6), 4 \cdot 8(0.5)$, and $5 \cdot 0$ $(0.5)$; with $40 \mathrm{mg} / \mathrm{kg}$ of ASA they were $4 \cdot 1(0 \cdot 7), 5 \cdot 3$ $(0.7), 5.6(0.6), 6.0(0.5)$, and $6.1(0.5)$. In every instance $n=8$. Results were similar with feeding salicylic acid but the difference was significant only at the higher dose of $40 \mathrm{mg} / \mathrm{kg}$.

\section{In presence of bacterial preparations}

Arbutin uptake in the presence of cell-free preparations of E. coli, Staphylococcus pyogenes, Candida albicans, and Klebsiella pneumoniae was significantly less than control values. Addition of $10 \mathrm{mM}$ salicylic acid to the incubation medium significantly increased arbutin uptake. Results are summarised in Table 1, which shows the mean values and standard errors of the mean arbutin uptake after 30 minutes incubation.

\section{In vivo FLUID TRANSPORT}

Effect of adding salicylate to perfusion fluid

Table 2 shows the effect on net water transport of adding $10 \mathrm{mM}$ salicylic acid to the perfusion fluid. Net secretion of fluid into the intestinal lumen occurred during perfusion with cell-free bacterial preparations of all the E. coli strains tested, Shigella sonnei, Salmonella typhimurium, Staphylococcus epidermidis, and Staphylococcus pyogenes and net water absorption was decreased with Candida tropicalis. In experiments with added salicylate water absorption was increased in control animals and in those perfused with cell-free preparations of E. coli 055, 263, 431, H10407 and B7A, Klebsiella pneumoniae, Shigella sonnei, Staphylococcus epidermidis, Staphylococcus pyogenes, and Salmonella typhimurium. The addition of salicylate did not alter net water transport in the presence of cell-free preparations of Candida tropicalis and net water absorption was decreased with and without added salicylate.

Table 1 Jejunal arbutin uptake in vitro ( $\mu m o l / m g$ of tissue) after incubation for 30 minutes

\begin{tabular}{lll}
\hline & $\begin{array}{l}\text { Without } \\
\text { salicylate }\end{array}$ & $\begin{array}{l}\text { With } 10 \mathrm{mM} \\
\text { salicylic acid }\end{array}$ \\
\hline Control & $3.45(0 \cdot 81)$ & $4.30(0.65) \dagger$ \\
E. coli & $1.52(0.74)^{*}$ & $4.59(0.03) \dagger$ \\
Staphylococcus & & \\
$\quad$ pyogenes & $2.28(0 \cdot 14)^{*}$ & $3.15(0.46) \dagger$ \\
Candida albicans & $2.76(0.13)^{*}$ & $6.34(0.56) \dagger$ \\
Klebsiella pneumoniae & $1.98(0 \cdot 15)^{*}$ & $5.27(0.51) \dagger$ \\
\hline
\end{tabular}

*Significantly less than control value $(\mathrm{P}<0.05)$.

†Significantly greater than value without salicylate $(\mathrm{P}<0.05)$.

SEM is given in parentheses. $n=10$ in each group.
Table 2 Effect of salicyclic acid on net flux of water during in vivo perfusion of rat jejunum with cell-free bacterial filtrates at $10 \mathrm{ml} / \mathrm{h}$

\begin{tabular}{|c|c|c|c|}
\hline \multirow[t]{2}{*}{ Organism } & \multirow[t]{2}{*}{$\begin{array}{l}\text { No. of } \\
\text { experiments }\end{array}$} & \multicolumn{2}{|c|}{$\begin{array}{l}\text { Mean net water flux } \\
(\mu \mathrm{l} / \mathrm{cm} / \mathrm{h})^{*}\end{array}$} \\
\hline & & $\begin{array}{l}\text { Without } \\
\text { salicylate }\end{array}$ & $\begin{array}{l}\text { With } \\
\text { salicylate }\end{array}$ \\
\hline Control & 8 & $50.4(7 \cdot 4)$ & $80 \cdot 2 \dagger(11 \cdot 2)$ \\
\hline E. coli 055 & 8 & $-22 \cdot 2(2 \cdot 6) \ddagger$ & $41 \cdot 6+(8 \cdot 6)$ \\
\hline E. coli $\mathrm{B} 7 \mathrm{~A}$ & 8 & $-12 \cdot 5(2 \cdot 3) \ddagger$ & $23 \cdot 4+(4 \cdot 5)$ \\
\hline E. coli $\mathrm{H} 10407$ & 8 & $-25 \cdot 6(2 \cdot 9) \ddagger$ & $27 \cdot 3+(3 \cdot 7)$ \\
\hline E. coli 431 & 8 & $-22 \cdot 2(3 \cdot 6) \ddagger$ & $12 \cdot 5 \dagger(2 \cdot 8)$ \\
\hline $\begin{array}{l}\text { E. coli } 263 \\
\text { Klebsiella }\end{array}$ & 8 & $-15 \cdot 2(3 \cdot 3) \ddagger$ & $35 \cdot 8+(6 \cdot 5)$ \\
\hline pneumoniae & 8 & $-51 \cdot 5(4 \cdot 4)$ & $41 \cdot 0 \dagger(8.4)$ \\
\hline $\begin{array}{l}\text { Shigella sonnei } \\
\text { Salmonella }\end{array}$ & 12 & $-42 \cdot 5(5 \cdot 9)$ & $65 \cdot 1 \dagger(7 \cdot 0)$ \\
\hline $\begin{array}{c}\text { typhimurium } \\
\text { Staphylococcus }\end{array}$ & 8 & $-10 \cdot 1(2 \cdot 0) \ddagger$ & $51 \cdot 2+(8 \cdot 2)$ \\
\hline $\begin{array}{l}\text { epidermidis } \\
\text { Staphylococcus }\end{array}$ & 8 & $-15 \cdot 6(4 \cdot 4) \ddagger$ & $50 \cdot 3+(7 \cdot 6)$ \\
\hline pyogenes & 8 & $-10.4(1.0)_{+}^{\ddagger}$ & $42 \cdot 7 \dagger(6 \cdot 5)$ \\
\hline $\begin{array}{l}\text { Candida } \\
\text { tropicalis }\end{array}$ & 12 & $18 \cdot 3(3 \cdot 0) \ddagger$ & $21 \cdot 2(3 \cdot 4)$ \\
\hline
\end{tabular}

*Negative values (-) indicate net secretion into intestinal lumen. †Indicates values significantly greater than perfusions without salicylate $(P<0.05)$.

$\ddagger$ Indicates values significantly less than controls. SEM is given in parentheses.

Effect of subcutaneous injection of salicylate after changes in net water flux were established

Net secretion of water occurred during the first hour of jejunal perfusion with preparation of E. coli B7A, H10407, 263 and 431, Klebsiella pneumoniae, Shigella sonnei, and Staphylococcus pyogenes while water absorption was significantly decreased with Candida tropicalis. One hour after subcutaneous injection of aspirin $(50 \mathrm{mg} / \mathrm{kg})$, water absorption was increased when preparations of E. coli 263 (LT only), Klebsiella pneumoniae, Shigella sonnei, or Staphylococcus pyogenes were perfused. With Candida tropicalis, E. coli B7A

Table 3 Effect of subcutaneous aspirin injection on changes in net water flux produced during in vivo perfusion of rat jejunum with cell-free bacterial filtrates at $10 \mathrm{ml} / \mathrm{h}$

\begin{tabular}{|c|c|c|}
\hline & \multicolumn{2}{|c|}{ Mean net water flux* $(\mu l / \mathrm{cm} / \mathrm{h})$} \\
\hline & Before s.c. aspirin & After s.c. aspirin \\
\hline E. coli 263 & $-19 \cdot 4(2 \cdot 7)$ & $17 \cdot 4(3 \cdot 4) \dagger$ \\
\hline E. coli 431 & $-44 \cdot 2(9 \cdot 6)$ & $-61 \cdot 5(13 \cdot 2)$ \\
\hline E. coli $\mathbf{B} 7 \mathbf{A}$ & $-11.8(3 \cdot 0)$ & $-12.0(3.6)$ \\
\hline E. coli $\mathrm{H} 10407$ & $-24 \cdot 2(4 \cdot 3)$ & $-64 \cdot 6(10 \cdot 1)$ \\
\hline Klebsiella pneumoniae & $-77 \cdot 3(11 \cdot 5)$ & $42.4(10.8) \dagger$ \\
\hline Shigella sonnei & $-37 \cdot 9(7 \cdot 5)$ & $48 \cdot 1(13 \cdot 1) \dagger$ \\
\hline Staphylococcus pyogenes & $-11 \cdot 1(2 \cdot 3)$ & $47.6(10.6) \dagger$ \\
\hline Candida albicans & $12 \cdot 5(3 \cdot 5)$ & $18 \cdot 7(3 \cdot 8)$ \\
\hline
\end{tabular}

*Negative values ( - ) indicate net secretion into intestinal lumen. †Indicates values significantly greater than results before aspirin injection $(\mathrm{P}<0.05)$.

$n=6$ in each group. SEM is in parentheses. 
$(\mathrm{LT}+\mathrm{ST}), \mathrm{H} 10407(\mathrm{LT}+\mathrm{ST})$, and 431 (ST only) there was either no change or an increase in water secretion. Results are shown in Table 3.

\section{Discussion}

The findings of the present study add support to previous observations that salicylates can lessen the intestinal secretory effects induced by toxigenic micro-organisms. We found that intestinal uptake of arbutin, a non-metabolised analogue of D-glucose, was increased by the addition of acetyl salicylic or salicylic acid to the incubation medium in experiments with rat jejunum mounted in plexiglass chambers. Similar results were found when measuring jejunal arbutin uptake in rats one hour after they were fed acetyl salicylic acid. These findings agree with the reported effects of aspirin on intestinal transport measured by changes in electrical gradient across the intestinal mucosa. ${ }^{9}$

Jejunal arbutin uptake in vitro was decreased in the presence of cell-free preparations of $E$. coli, Staphylococcus pyogenes, Candida albicans, and Klebsiella pneumoniae. Arbutin uptake was then increased with each of these organisms after the addition of $10 \mathrm{mM}$ salicylic acid to the incubation medium. This effect is similar to that of acetyl salicylic acid on electrical gradient across intestinal mucosa exposed to cholera toxin. ${ }^{9}$

In vivo, salicylates were found to increase net water absorption in rat jejunum exposed to cell-free preparations of several strains of E. coli, Klebsiella pneumoniae, Shigella sonnei, Salmonella typhimurium, Staphylococcus epidermidis, and Staphylococcus pyogenes as well as in control animals perfused with uninoculated culture medium processed identically. Net water flux in the presence of preparations of Candida tropicalis was not affected by the addition of salicylate. These results are similar to the reported effects of salicylate on cholera toxin and $E$. coli LT-induced water secretion ${ }^{46}$ as well as the effects of indomethacin on cholera toxin and fluid secretion induced by Salmonella typhimurium and Shigella flexneri. $^{?}$

When salicylate was given by subcutaneous injection after changes in net water flux were established by perfusion with bacterial preparations, water absorption increased with $E$. coli 263 (LT only) but not with strains of $E$. coli producing ST either alone or in combination with LT. Absorption of water increased when Klebsiella pneumoniae, Shigella sonnei, and Staphylococcus pyogenes were the test organisms but not when Candida albicans was used. All the organisms causing secretion which was then affected by subcutaneous injection of aspirin are those we have found to increase activity of adenylate cyclase in vitro using the pigeonerythrocyte lysate assay. ${ }^{18}$ The strains of $E$. coli causing changes in net water flux which were unaffected by injection of aspirin were either strains of $E$. coli producing ST only which did not increase adenylate cyclase or those producing ST as well as LT which, although increasing adenylate cyclase activity, also had ST able to produce fluid secretion by a different mechanism. ${ }^{19}$ Candida albicans did not increase adenylate cyclase and also produced changes in net water flux which were unaffected by subcutaneous injection of aspirin. Intestinal monosaccharide absorption has been reported to be decreased in the presence of several enterotoxins $^{2} 20$ although cholera toxin has not been shown to affect glucose absorption. ${ }^{21}$ The link between intestinal transport of sugars and sodium is well established. In earlier experiments we showed that net intestinal sodium flux parallels changes in net water flux induced by bacterial enterotoxins. ${ }^{3}$ It has been suggested that sodium influx may be cyclic nucleotide dependent even in the absence of toxin-induced electrolyte secretion. ${ }^{9}$ The effects of aspirin on monosaccharide absorption may therefore be mediated by the influence of cyclic nucleotides on intestinal sodium transport. The present observations are compatible with the suggestion that the absorptive and anti-secretory effects of aspirin are cyclic nucleotide dependent.

Subcutaneous injection of aspirin has been shown to be effective in decreasing fluid secretion induced by cholera toxin, ${ }^{4}$ although in that study the aspirin was given at the same time as ileal loops were exposed to cholera toxin. Farris et al., ${ }^{9}$ investigating the effect of aspirin added to the mucosal or serosal surfaces of rabbit ileal mucosa, found aspirin to be significantly more effective when added to the serosal side of the intestine. This led those authors to suggest that blood levels of aspirin, rather than luminal levels, may be important in preventing the effects of cholera toxin.

However, Nalin ${ }^{10}$ was unable to control cholera toxin-induced fluid secretion in dogs by adding aspirin to the contents of jejunal loops after changes in net water flux were established. Later, Ericsson et $a l^{6}$ found that addition of bismuth subsalicylate to the contents of ileal loops in rabbits failed to prevent activity of $E$. coli or cholera toxin when given after water secretion had begun, although it was effective when given at the same time as the toxins.

We have found differences in the effectiveness of salicylates given at the same time as the toxin and when administered by injection after the net water flux had been affected. When given with bacterial preparations into the intestinal lumen, 
salicylates were effective with all organisms tested except Candida sp. Aspirin given by injection after fluid secretion had been induced by bacterial preparations appeared to be effective only with organisms producing fluid secretion only via activation of adenylate cyclase. The effect of $E$. coli ST, which does not act in this way, appears to persist after injection of aspirin. Failure to demonstrate an effect of aspirin given intraluminally after intestinal loops had been exposed to enterotoxins may be explained by inadequate blood levels of salicylate being attained.

Our results clearly show that salicylates are capable of antagonising toxin-induced intestinal fluid secretion even when given after exposure to the toxin. While this is not effective with all organisms tested, the range of bacteria affected suggests that the treatment may be useful clinically, particularly in malnourished children who are likely to have mixed bacterial overgrowth in the upper small intestine. ${ }^{122}{ }^{23}$ These experimental data combined with the report that aspirin is useful in reducing diarrhoea in patients with radiationinduced enteritis ${ }^{24}$ who may also have bacterial overgrowth in the small intestine, ${ }^{25}$ suggest that a clinical trial of salicylates in malnourished children with diarrhoea would be appropriate.

This work was supported by a grant from the Wellcome Trust, London. Salicylic acid and acetyl salicyclic acid used in this study was supplied by Nicholas International Ltd.

\section{References}

${ }^{1}$ Gracey M, Suharyono, Sunoto, Stone DE. Microbial contamination of the gut: another feature of malnutrition. Am J Clin Nutr 1973; 26: 1170-4.

${ }^{2}$ Burke V, Houghton M, Gracey M. Effect of enteric micro-organisms on intestinal sugar and fatty acid absorption. Aust J Exptl Biol Med Sci 1977; 55: 423-9.

${ }^{3}$ Thelen P, Burke V, Gracey M. Effects of intestinal micro-organisms on fluid and electrolyte transport in the jejunum of the rat. J Med Microbiol 1978; 11: 463-70.

${ }^{4}$ Jacoby HI, Marshall CH. Antagonism of cholera enterotoxin by anti-inflammatory agents in the rat. Nature 1972; 235: 163-5.

${ }^{5}$ Finck AD, Katz RL. Prevention of cholera induced intestinal-secretion in the cat by aspirin. Nature 1972; 238: $273-4$.

${ }^{6}$ Ericsson CD, Evans DG, DuPont HL, Evans DJ Jr, Pickering LK. Bismuth subsalicylate inhibits activity of crude toxins of Escherichia coli and Vibrio cholerae. $J$ Infect Dis 1977; 136: 693-6.
${ }^{7}$ Gots RE, Formal SB, Giannella RA. Indomethacin inhibition of Salmonella typhimurium, Shigella flexneri and cholera mediated rabbit ileal secretion. J Infect Dis 1974; 130: $280-4$.

${ }^{8}$ Madsen GL, Knoop FC. Inhibition of the secretory activity of Escherichia coli heat stable enterotoxin by indomethacin. Infect Immun 1978; 22: 143-7.

${ }^{9}$ Farris RK, Tapper EJ, Powell DW, Morris SM. Effect of aspirin on normal and cholera toxin-stimulated intestinal electrolyte transport. J Clin Invest 1976; 57: 916-24.

${ }^{10} \mathrm{Nalin}$ DR. Failure of aspirin to reverse intestinal secretion after cholera toxin in dogs (letter). Lancet 1976; 2 : 576.

${ }^{11}$ Dafni Z, Robbins JB. Purification of heat-labile enterotoxin from Escherichia coli 078 : $\mathrm{H} 11$ by affinity chromatography with antiserum to Vibrio cholerae toxin. J Infect Dis 1976; 133: S138-41.

${ }^{12}$ Krebs HA, Henseleit K. Untersuchungen über die Harnstoffbildung im Tierkörper. Hoppe-Seylers $Z$ Physiol 1932; 210: 33-66.

${ }^{13}$ Semenza G. Studies on intestinal sucrase and sugar transport. VII. A method for measuring intestinal uptake. The absorption of the anomeric forms of some monosaccharides. Biochim Biophys Acta (Amst) 1969; 173: 104-12.

${ }^{14}$ Somogyi M. Notes on sugar determination. $\mathrm{J} \mathrm{Biol} \mathrm{Chem}$ 1952; 195: 19-23.

${ }^{15}$ Folin O, Ciocalteu V. On tyrosine and tryptophane determination in proteins. $J$ Biol Chem 1927; 73: 627-50.

${ }^{16}$ Waravdekar VS, Saslaw LD. A method of estimation of 2-deoxyribose. Biochim Biophys Acta (Amst) 1957; 24: 439.

${ }^{17}$ Burke V, Malajczuk A, Gracey M, Speed TP, Thornett ML. Intestinal transport of monosaccharide after biliary diversion in the rat. Aust J Exptl Biol Med Sci 1978; 56: 253-63.

${ }^{18}$ Gill DM, King CA. The mechanism of action of cholera toxin in pigeon erythrocyte lysates. $J$ Biol Chem 1975; 250: 6424-32.

${ }^{19}$ Field M. Mechanisms of action of cholera and Escherichia coli enterotoxins. Am J Clin Nutr 1979; 32: 189-96.

${ }^{20} \mathrm{~K}$ lipstein FA, Horowitz IR, Engert RF, Schenk EA. Effect of Klebsiella pneumoniae enterotoxin on intestinal transport in the rat. $J$ Clin Invest 1975; 56: 799-807.

${ }^{2}$ Serebro HA, Bayless TM, Hendrix TR, Iber FL, McGonagle TJ. Absorption of d-glucose by the rabbit jejunum during cholera toxin-induced diarrhoea (letter). Nature (Lond.) 1968; 217: 1272-3.

${ }^{22}$ Heyworth B, Brown J. Jejunal microflora in malnourished Gambian children. Arch Dis Childh 1975; 50: 27-33.

${ }^{23}$ Rowland MGM, McCollum JPK. Malnutrition and gastroenteritis in the Gambia. Trans Roy Soc Trop Med Hyg 1977; 71 : 199-203.

${ }^{24}$ Mennie AT, Dalley VM, Dinneen LC, Collier HOJ. Treatment of radiation-induced gastrointestinal distress with acetyl salicylate. Lancet 1975 ; 2 : 942-3.

${ }^{25}$ Earnest DL, Trier JS. Radiation enteritis and colitis. In: Sleisenger MH, Fordtran JS, eds. Gastrointestinal disease. 2nd ed. Philadelphia: Saunders, 1978: 1736-45. 